\title{
Charlotte Scott. Shakespeare's Nature: From Cultivation to Culture. Oxford: Oxford University Press, 2014. Pp 257.
}

SARAH O'MALLEY

University of Nottingham
Early Theatre 19.1 (2016), 161-3

http://dx.doi.org/10.12745/et.19.1.2907

In Shakespeare's Nature Charlotte Scott looks to illuminate the importance of the language of husbandry to the literary works of Shakespeare. Beyond this, Scott looks into the depths of Shakespeare's engagement with agrarian culture and the impact it had not just as metaphorical ammunition, but as the foundation for a particular understanding of self and society. Scott seeks to recover the deep connection between early modern writers and agrarian practices that has, perhaps, been lost to a modern reader.

As Scott astutely points out at the start of the book, Shakespeare's family heritage was firmly rooted in agricultural occupations, and this 'agrarian landscape to which Shakespeare belonged defined both the social and economic values of Elizabethan England' (1). Building on considerable scholarship in the field of early modern agrarian studies (by Andrew McRae and Joan Thirsk to name but two), Scott performs the important task of returning a significant and often overlooked context to the study of Shakespeare. ${ }^{1}$ Looking in detail at the evolving religious and social resonances of agrarian connection to the land through the analysis of a variety of pamphlet material, Scott charts the evolving language of husbandry and its deployment as social and moral commentary in the Shakespearean canon and beyond.

Chapter 2 begins this study with an analysis of the sonnets, focusing on a humanist tradition of self-mastery and potential that connects mastery over self/ body to mastery over the land. Scott works to establish the importance of the discourse of cultivation in creating a moral obligation to ensure that both landscapes and (female) bodies become sites of production, as well as establishing them as sites through which to display personal legacy and achievement. Both the land and the female body become 'sites of duty in which yield and fertility represent a moral turnover' (64); failure to achieve this yield or to show ample fertility positions both the land and the body as sites of personal and social failure, as well as missed opportunities for moral and social gain. With an interesting analysis of the gender dynamics at work in the inscription of the female body as site of economic (re)production, Scott convincingly shows the moral, economic, and social connections that a discourse of cultivation forges between the womb and the landscape as sites of production. 
Chapter 3 focuses specifically on the latter half of Henry $V$, and lingers with particular nuance on Burgundy's speech in act 5. Looking to establish the centrality of husbandry to 'the terms of both war and peace' (84), this chapter argues for the important connotations of agrarian order to those of social order and security. Henry's development from a wild youth to a cultivated, productive adult finds its culmination in Burgundy's speech and his subtle directives for Henry to cement his and his nation's stability through his correct husbandry of the country following military victory. Through her analysis of the play, and Burgundy's speech in particular, Scott explores the intertwining of the morality of military, agrarian, and social interventions through the language of husbandry, and the importance of these interventions in establishing national identity and the success of a nation's leaders.

The most surprising, but also perhaps most interesting, selection and analysis of material comes in chapter 4, which offers an analysis of Macbeth and the 'Poetics of the Unnatural'. In this chapter Scott charts the increasing use of nature as a tool to express human values and, through the lens of Macbeth's protagonists, shows the rejection and testing of the boundaries of the natural as the ultimate expression of cultural superiority and individualism. Scott's analysis of Lady Macbeth marks the second extended engagement with gender and, whilst not one of the book's central concerns, indicates that the work begun here could be continued to look further at the engagement of discourses of cultivation with those of gender. With some truly novel insights into the unnatural actions of the Macbeths as a framework through which the tension between individual will and human nature is explored, this chapter offers a refreshing analysis of a play that is not often associated with the agrarian.

In her analysis of The Winter's Tale in chapter 5, Scott explores the transition from religious to more consumerist understandings of cultivating the land. Early modern authors begin to co-opt religious discourses of hard work on the land as atonement into a new discourse of production associating this hard work with financial rather than spiritual reward. Scott suggests that, within literature of the early modern period, the pastoral moves away from escapist fantasies towards fantasies of consumerism driven by the growing 'purchasing potential of the rural class' (152). Scott explores the interrogation of these competing discourses in The Winter's Tale, as well as continuing the investigation begun in previous chapters into the relationship, and sometimes conflict, between organic nature and human intervention.

Chapter 6 offers a reading of The Tempest. Particularly interesting is Scott's analysis of the masque within The Tempest and its use of a cultivated English 
landscape as a framework through which Prospero can express legitimate desire and social order in his otherwise chaotic, unstructured surroundings. Developing the connections between cultivation and religion, Scott also explores further the notion of cultivation as increasingly becoming shorthand for civilization and morality. In an extended study of the differences between Gonzalo's and Prospero's relationships (both real and speculative) to the landscape, Scott eloquently illuminates the relationship between human intervention on the landscape and evidence of the moral fabric of society in early modern English thought. In the context of The Tempest this relationship obviously has colonial overtones, and has the potential for further exploration as early modern literary studies return increasingly to analysis of American colonial landscapes. Recent studies by Gavin Hollis and David McInnis, for example, have offered fresh, innovative approaches to early modern literature's engagement with the English colonial endeavour, and with the language and practice of husbandry being so central to English presence in the new world, Scott's analysis could add further depth to the new directions being explored in this field. ${ }^{2}$

Scott's close readings of the differing linguistic registers of the discourse of husbandry across a wide variety of genres and texts illuminate the complexity and richness of agrarian language in early modern literature. Although the focus on Shakespeare means that Scott's work is inevitably far from exhaustive, what Scott has achieved here is a thorough and cohesive study that confidently asserts the importance of the language of husbandry and cultivation to Shakespeare's work, while opening up future directions for research. The implications of Scott's approach beyond Shakespeare, for example to the presence of agrarian language in city comedies, or as noted above in relation to colonial discourses, gender, sexuality, and racial discourses, mean that the work here offers the potential for new and exciting insight into other, long standing areas of study.

\section{Notes}

1 Major studies include Andrew McRae, God Speed the Plough: The Representation of Agrarian England, 1500-1660 (Cambridge, 1996); Joan Thirsk, Agricultural Regions and Agrarian History in England, 1500-1750 (Basingstoke, 1987).

2 Gavin Hollis, The Absence of America: The London Stage, 1576-1642 (Oxford, 2015); David McInnis, Mind-Travelling and Voyage Drama in Early Modern England (Basingstoke, 2014). 